\title{
Vitamin D increases programmed death receptor-1 expression in Crohn's disease
}

\author{
Mia Bendix ${ }^{1}$, Stinne Greisen ${ }^{2,3}$, Anders Dige ${ }^{1}$, Christian L. Hvas ${ }^{1}$, Nina Bak ${ }^{1}$, Søren \\ P. Jørgensen ${ }^{1}$, Jens F. Dahlerup ${ }^{1}$, Bent Deleuran ${ }^{2,3}$ and Jørgen Agnholt ${ }^{1}$ \\ ${ }^{1}$ Department of Hepatology and Gastroenterology, Aarhus University Hospital, Aarhus, Denmark \\ 2 Department of Immunology, Institute of Biomedicine, Aarhus University, Aarhus, Denmark \\ ${ }^{3}$ Department of Rheumatology, Aarhus University Hospital, Aarhus, Denmark \\ Correspondence to: Mia Bendix, email: mb@clin.au.dk
}

Keywords: PD-1, Crohn's disease, vitamin D, T cells, Immunology and Microbiology Section, Immune response, Immunity Received: November 18,2016 Accepted: February 07, 2017 Published: February 18, 2017

Copyright: Bendix et al. This is an open-access article distributed under the terms of the Creative Commons Attribution License (CC-BY), which permits unrestricted use, distribution, and reproduction in any medium, provided the original author and source are credited.

\section{ABSTRACT}

Background: Vitamin D modulates inflammation in Crohn's disease (CD). Programmed death (PD)-1 receptor contributes to the maintenance of immune tolerance. Vitamin D might modulate PD-1 signalling in CD.

Aim: To investigate PD-1 expression on T cell subsets in CD patients treated with vitamin D or placebo.

Methods: We included 40 CD patients who received 1200 IU vitamin D3 for 26 weeks or placebo and eight healthy controls. Peripheral blood mononuclear cells (PBMCs) and plasma were isolated at baseline and week 26. The expressions of PD1, PD-L1, and surface activation markers were analysed by flow cytometry. Soluble PD-1 plasma levels were measured by ELISA.

Results: PD-1 expression upon T cell stimulation was increased in CD4+CD25+int $T$ cells in vitamin D treated CD patients from $19 \%$ (range $10-39 \%$ ) to $29 \%(11-$ $79 \%)(p=0.03)$ compared with placebo-treated patients. Vitamin $D$ treatment, but not placebo, decreased the expression of the T cell activation marker CD69 from $42 \%$ $(31-62 \%)$ to $33 \%(19-54 \%)(p=0.01)$. Soluble PD-1 levels were not influenced by vitamin $D$ treatment.

Conclusions: Vitamin D treatment increases $C D 4^{+}{ }^{+} D 25^{+i n t} T$ cells ability to upregulate PD-1 in response to activation and reduces the CD69 expression in CD patients.

\section{INTRODUCTION}

Vitamin D has important immunomodulating functions, which may influence the natural course of autoimmune diseases. In Crohn's disease (CD), vitamin $\mathrm{D}$ deficiency is common [1,2] and associated with both a low quality of life [3] and an increased disease activity [4,5]. A randomised clinical trial indicated that oral vitamin $\mathrm{D}$ treatment reduces the relapse rate and disease activity [6]. Vitamin D's effect on CD may be due to the modulation of cellular immune responses. Following 26 weeks of oral vitamin D treatment to CD patients, T cells decreases the ability to up-regulate the vitamin $\mathrm{D}$ receptor (VDR) [7]. Further, in vitro 25-hydroxyvitamin D3 (25vitD) and 1.25-dihydroxyvitamin $\mathrm{D} 3 \quad\left(1.25(\mathrm{OH})_{2} \mathrm{D}\right)$ stimulation reduces the differentiation of T-helper 17
(Th17) cells and decreases the production of interferon (IFN)- $\gamma$ and interleukin (IL)-17 [8]. Also, in vitro $1 \alpha, 25-$ dihydroxyvitamin D3 stimulation promotes regulatory T cells (Treg) function [9]. Still, the influence of oral vitamin $\mathrm{D}$ on $\mathrm{T}$ cells is not elucidated.

$\mathrm{CD}$ is characterised by transmural mucosal inflammation dominated by a loss of tolerance towards the commensal intestinal microbiota [10]. The regulation of immunological tolerance plays a critical role in CD [11]. Programmed death (PD)-1 is a co-inhibitory receptor, which is expressed by activated $\mathrm{T}$ cells, $\mathrm{B}$ cells, and Natural Killer cells [12] and is involved in maintenance of immune tolerance. Upon binding with the ligands PDL1 and PD-L2, which are expressed by haematopoietic lineage cells and antigen presenting cells [13], PD-1 inhibits $\mathrm{T}$ cell function, survival, and activation [14]. 
Table 1: Baseline patient characteristics.

\begin{tabular}{|l|c|c|c|}
\hline & Vitamin D & Placebo & $\boldsymbol{p}$ value \\
\hline$N$ & 20 & 20 & NA \\
\hline Male, $n$ & 11 & 10 & 0.75 \\
\hline Age (median, range) & $33(21-62)$ & $36(19-66)$ & 0.42 \\
\hline Winter inclusion*, $n$ & 17 & 19 & 0.29 \\
\hline Smokers, $n$ & 6 & 8 & 0.51 \\
\hline Azathioprine users, $n$ & 12 & 3 & 0.003 \\
\hline Biologicals prior to inclusion, $n$ & 3 & 3 & 1.00 \\
\hline
\end{tabular}

Crohn's disease patient characteristics at baseline. The two groups did not differ except for the use of azathioprine where more patients in the vitamin D group used azathioprine compared with the placebo group.

* Winter inclusion; $1^{\text {st }}$ of October to $31^{\text {th }}$ of March, summer inclusion; $1^{\text {st }}$ of April to $30^{\text {th }}$ of September.

By this way, PD-1 serves to hinder auto-reactive T cell responses [15]. PD-1 and the PD-1 ligands also exist in soluble forms. Soluble (s) PD-1 is elevated in several autoimmune diseases such as diabetes mellitus [16], systemic lupus erythematosus, and rheumatoid arthritis (RA) $[17,18]$. In RA, sPD-1 levels are associated with increased disease activity and clinical scores [19].

PD-1 expression is increased in exhausted T cells, which are identified in patients with chronic infections and autoimmune diseases [20-22]. Exhausted T cells which contribute to peripheral tolerance [23] are associated with less flare-ups in IBD[21].

In mucosal lamina propria cells, PD-1 and PDL1 expressions are up-regulated in inflammatory bowel disease compared with healthy controls [24]. In murine colitis models, PD-L1-Fc treatment decreased the disease activity and the Th17 cell frequency, together with an increased $\mathrm{CD}^{+} \mathrm{T}$ cell-mediated IL-10 production [25]. Taken together, PD-1 function may contribute to the disrupted $\mathrm{T}$ cell functions in autoimmune diseases such as CD.

Vitamin D influences the PD-1 pathway by increasing the PD-L1 expression and decreasing the expression of the co-stimulatory receptors CD80 and CD86 following lipopolysaccharides (LPS) stimulation in monocyte-derived dendritic cells (DCs) from healthy controls [26]. In mice, this effect has also been observed in bone marrow-derived DCs [27].

We hypothesized that oral vitamin D treatment modulates PD-1 signalling in CD and aimed to investigate the PD-1 expression in T cells from CD patients who had received oral vitamin $\mathrm{D}$ or placebo.

\section{RESULTS}

\section{Effects of vitamin D treatment in CD patients}

Baseline patient characteristics of the $40 \mathrm{CD}$ patients included in this study are presented in Table 1. At baseline, patients randomised to vitamin D and placebo did not differ, except from increased use of azathioprine in the vitamin D treated group $(p=0.003)$. The baseline plasma 25-vitD levels were comparable between the two groups (vitamin D group $38 \mathrm{nmol} / \mathrm{l}$ (16 - 75), placebo group 49 nmol/1 (22 - 81), $p=0.35)$. Baseline 25-vitD levels did not correlate with faecal calprotectin, C-reactive protein (CRP), Harvey-Bradshaw Index (HBI), or Crohn's Disease Activity Index (CDAI) scores (data not shown). In the vitamin D group, 25-vitD levels increased 3-fold from baseline to 26 weeks of treatment $(p<0.0001)$ (Figure $1 \mathrm{~A}$ ) in contrast to no effect on the 25 -vitD levels in the placebo group.

Among patients randomised to vitamin $\mathrm{D}$, the CDAI and HBI scores, the biochemical inflammation marker CRP and the mucosal marker faecal calprotectin remained unchanged during the treatment period. Among patients randomised to placebo, faecal calprotectin increased from $64 \mathrm{mg} / \mathrm{kg}(20-1250)$ to $161 \mathrm{mg} / \mathrm{kg}(20-1250)$ ( $p=$ 0.01 ) after 26 weeks of treatment (Figure 1B). CDAI, too, increased slightly during placebo treatment from 32 ( 0 $140)$ to $42(12-140)(p=0.05)$. Six out of the 20 placebo patients experienced clinical relapse during one year of follow up while none of the vitamin $\mathrm{D}$ treated patients relapsed $(p=0.008)$. Four out of six placebo patients relapsed before week 26 and were excluded from the week 26 analyses. Two out of six placebo patients relapsed later than week 26, and these patients were included in week 26 analyses. Therefore all included patient samples were obtained during remission.

\section{Vitamin D treatment induces PD-1 expression in activated $T$ cells and changes their activation pattern}

Vitamin D treatment did not affect the PD-1 expression in unstimulated or $\mathrm{T}$ cell receptor- (TCR) stimulated $\mathrm{CD}^{+}$and $\mathrm{CD}^{+} \mathrm{T}$ cells in general (data not shown). We subsequently focussed our analysis to the subset of activated $\mathrm{CD}^{+} \mathrm{T}$ cells expressing the activation marker CD25, which comprised $95 \%$ of the total population of $\mathrm{CD}^{+} \mathrm{T}$ cells. Because CD25 is highly 
expressed by regulatory $\mathrm{T}$ cells, the CD25 expressing $\mathrm{CD}^{+} \mathrm{T}$ cells were further subdivided into regulatory $\mathrm{T}$ cell-enriched $\mathrm{CD} 4^{+} \mathrm{CD} 25^{\text {thigh }}\left(\mathrm{CD} 4^{+} \mathrm{CD} 25^{\text {thi }}\right)$ and activated CD $4^{+} \mathrm{CD} 25^{\text {+intermediate }}\left(\mathrm{CD} 4^{+} \mathrm{CD} 25^{+ \text {int }}\right)$ (Figure S1). Vitamin $\mathrm{D}$ treatment increased the PD-1 expression upon TCR stimulation, in $\mathrm{CD}^{+} \mathrm{CD} 25^{\text {int }} \mathrm{T}$ cells from baseline $19 \%$ (range $10-39 \%)$ to $29 \%(11-79 \%)(p=0.03)$, while the expression remained unchanged in patients who received placebo (Figure 2A). PD-1 increase in CD4+CD25+int T cells was not associated to the use of azathioprine (data not shown). The percentage of $\mathrm{CD} 4{ }^{+} \mathrm{CD} 25^{\text {int }} \mathrm{T}$ cells of live cells was not affected by oral vitamin $\mathrm{D}$ treatment (data not shown). Neither vitamin $\mathrm{D}$ nor placebo treatment influenced the $\mathrm{CD} 4^{+} \mathrm{CD} 25^{\text {thi }} \mathrm{T}$ cells' PD-1 expression following TCR stimulation (Figure 2B).

To further examine the influence of vitamin $\mathrm{D}$ on the PD-1 expression in $\mathrm{CD} 4^{+} \mathrm{CD} 25^{+ \text {int }}$ and $\mathrm{CD} 4^{+} \mathrm{CD} 25^{\text {thi }} \mathrm{T}$ cells, levels of $\mathrm{CD} 4^{+} \mathrm{CD} 25^{\text {+int }} \mathrm{PD}-1^{+}$and $\mathrm{CD} 4^{+} \mathrm{CD} 25^{\text {thi PD }} 1^{+}$subsets were correlated to 25 -vitD levels at baseline. 25-vitD plasma levels were associated both with the percentage of $\mathrm{CD} 4^{+} \mathrm{CD} 25^{\text {thi PD }}-1^{+}$cells $(\mathrm{p}<0.05$, Spearman's rho $=0.45)$ (Figure $2 \mathrm{C})$ and


(Figure 2D).

The activation pattern of the $T$ cells was changed by vitamin $\mathrm{D}$ treatment. In the vitamin D group, CD69 up-regulation upon TCR stimulation was reduced from baseline $42 \%(31-62 \%)$ to $33 \%(19-54 \%)(p=0.01)$. This was not observed in the placebo group (Figure 3 ). The baseline CD69 expression was higher in the placebo group compared with the vitamin D group. CD69 expression was not associated with use of azathioprine (data not shown).

\section{Soluble PD-1 is unaffected by vitamin D treatment}

We investigated whether vitamin $\mathrm{D}$ treatment affected SPD-1 concentrations in plasma from vitamin D and placebo treated $\mathrm{CD}$ patients in remission and from healthy controls $(\mathrm{HC})$ treated with high dose vitamin D for 15 days. Soluble PD-1 was detectable in both CD patients and $\mathrm{HC}$, but plasma levels were clinically unaffected by vitamin D treatment in both CD patients (from $0.092 \mathrm{ng}$ / $\mathrm{ml}(0.269-0.05)$ to $0.085 \mathrm{ng} / \mathrm{ml}(0.209-0.05), p=0.09)$ and $\mathrm{HC}$ (from $0.072 \mathrm{ng} / \mathrm{ml}(0.173-0.05)$ to $0.062 \mathrm{ng} / \mathrm{ml}$ $(0.108-0.05), p=0.5)$ and likewise in placebo treated CD patients (from $0.05 \mathrm{ng} / \mathrm{ml}(0.155-0.05)$ to $0.05 \mathrm{ng} /$ $\mathrm{ml}(0.05), p=0.03$ ) (data not shown). Soluble PD-1 levels were not associated with inflammation markers and the disease scores in the group of CD patients at baseline (CDAI, HBI, CRP, and faecal calprotectin)(data not shown).

\section{$1.25(\mathrm{OH})_{2} \mathrm{D}$ activates $\mathrm{T}$ cells and decreases PD-1 expression in cell cultures}

We tested how in vitro $1.25(\mathrm{OH})_{2} \mathrm{D}$ stimulation affected the PD-1 expression on T cells at baseline. The vitamin $\mathrm{D}$ and placebo treated groups were examined


Figure 1: Effects of vitamin D treatment in CD patients. Clinical parameters are shown at baseline ( 0 weeks $)$ and after 26 weeks of treatment with vitamin D or placebo. Circles represent vitamin D treated CD patients and triangles placebo treated CD patients. Solid lines represent medians. A. 25-hydroxyvitamin D levels increased in the vitamin D group but not in the placebo group. The vitamin D treated patients were selected on the basis of an increase in 25 -hydroxyvitamin D within 26 weeks of treatment. B. Faecal calprotectin levels at baseline and after 26 weeks of treatment. Calprotectin levels were unchanged in the vitamin D group but increased in the placebo group. Range from 20 to $1250 \mathrm{mg} / \mathrm{kg}$. N; number. 
together in one group (CD patients). Three days of TCRmediated stimulation resulted in an up-regulated PD-1 expression on $\mathrm{CD} 4+$ and CD8 $+\mathrm{T}$ cells in both $\mathrm{CD}$ patients and HC. The PD-1 expression in CD4+ T cells increased more in CD patients (from $1 \%(0-3 \%)$ to $16 \%(3-27 \%)$ ) than in $\mathrm{HC}$ (from $0 \%(0-2 \%)$ to $6 \%(2-18 \%))(p=$ 0.002 ) (Figure $4 \mathrm{~A})$. In contrast, the $\mathrm{CD} 8^{+} \mathrm{PD}-1^{+}$increase was similar in CD patients and HC (Figure 4B) upon TCR stimulation. Addition of $1.25(\mathrm{OH})_{2} \mathrm{D}$ inhibited the PD-1 up-regulation in both $\mathrm{CD}^{+} \mathrm{T}$ cells (from $16 \%(3-27 \%)$ to $9 \%(2-30 \%))(p=0.0009)$ and $\mathrm{CD}^{+} \mathrm{T}$ cells (from $11 \%(1$ - $26 \%)$ to $4 \%(0-12 \%))(p<0.0001)$ (Figure $4 \mathrm{~A}$ and $4 \mathrm{~B}$ ). This pattern was unaffected after 26 weeks of treatment with vitamin D or placebo (data not shown).

We observed a universal up-regulation of PD-L1 on all peripheral blood mononuclear cells (PBMCs) after
A

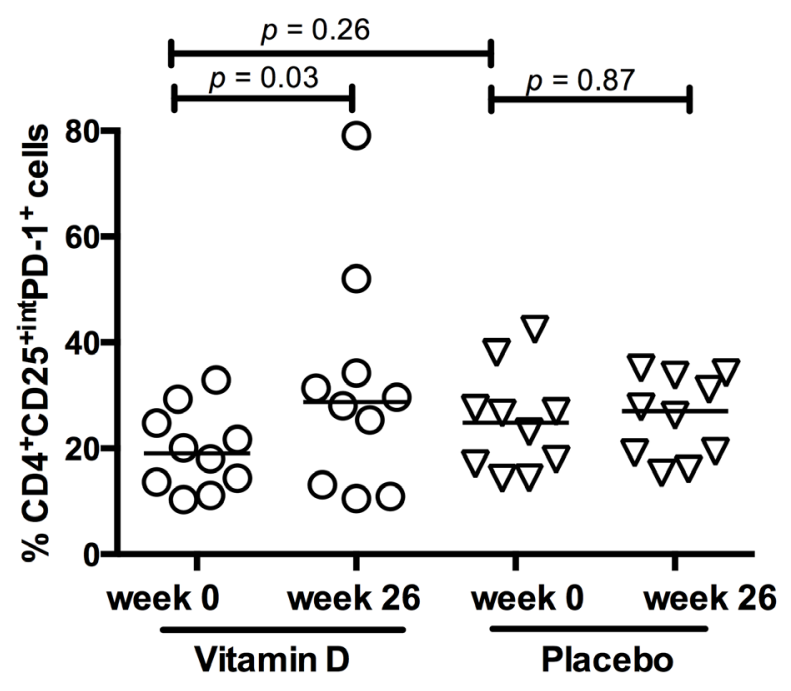

C

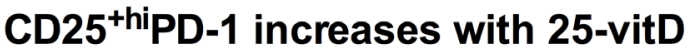

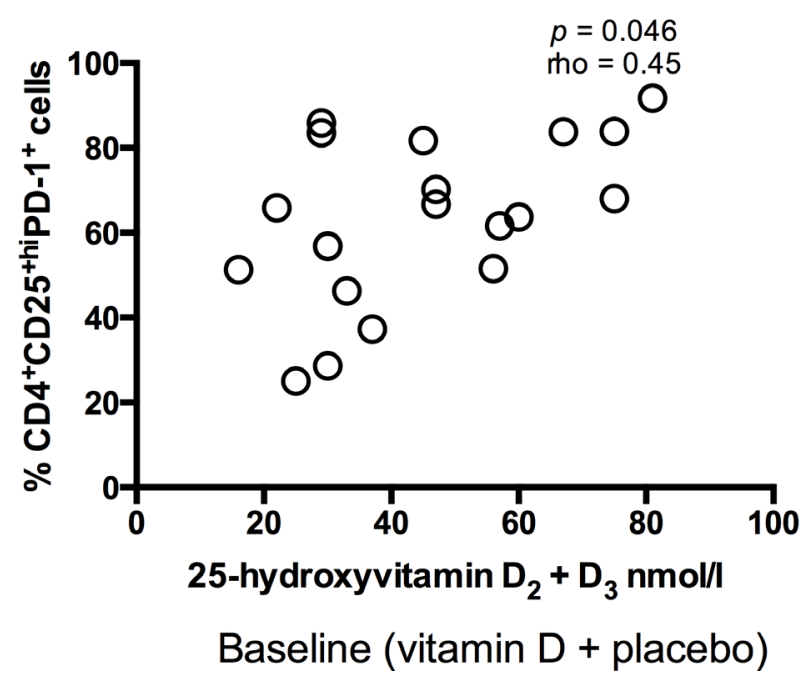

B

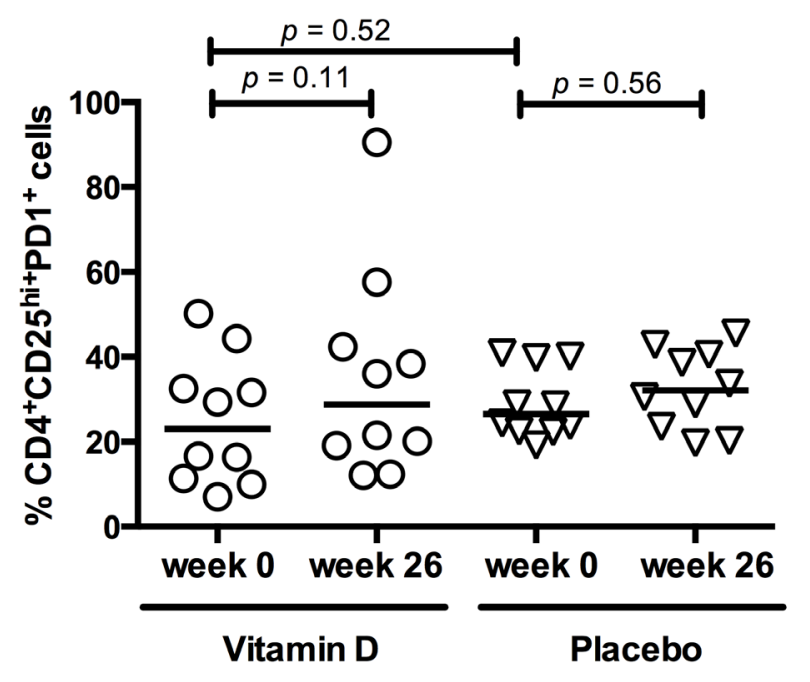

D

\section{CD25 ${ }^{\text {int }}$ PD- $1^{+}$is associated to 25 -vitD}

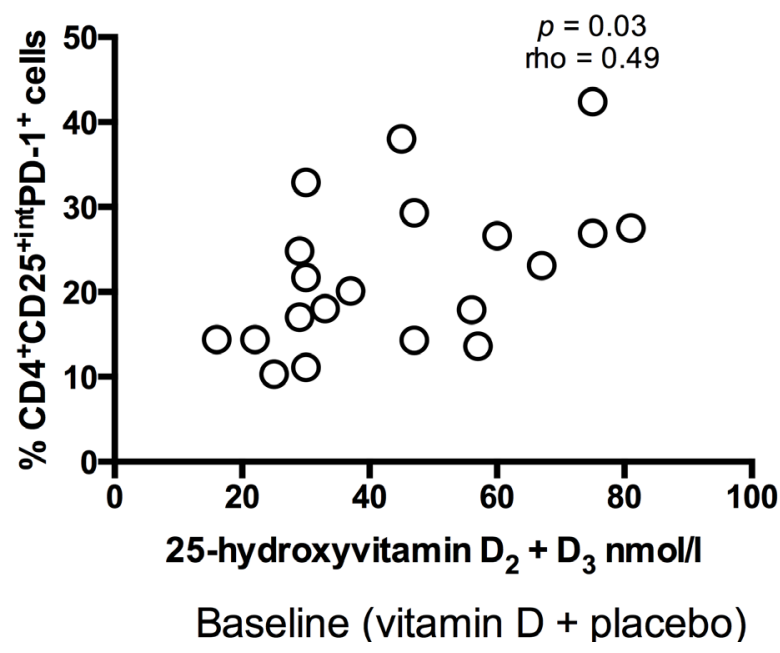

Figure 2: Vitamin D treatment induces PD-1 expression in active $\mathbf{T}$ cells. Solid lines represent medians, circles represent vitamin $\mathrm{D}$ treated $\mathrm{CD}$ patients $(N=10)$ and triangles placebo treated $\mathrm{CD}$ patients $(\mathrm{N}=10)$. The $\mathrm{CD} 4{ }^{+} \mathrm{CD} 25^{+}$population was divided into $\mathrm{CD} 4^{+} \mathrm{CD} 25^{\text {thi }}$ and $\mathrm{CD} 4^{+} \mathrm{CD} 25^{\text {tint }}$. A. Vitamin D treatment increased PD-1 expression in $\mathrm{CD} 4^{+} \mathrm{CD} 25^{\text {tint }} \mathrm{T}$ cells compared to placebo treatment. B. PD-1 expression in CD4 $4^{+} \mathrm{CD} 25^{\text {thigh }}$ cells was not affected by treatment. C. 25 -hydroxyvitamin D levels are associated with the percentage of $\mathrm{CD} 4^{+} \mathrm{CD} 25^{\text {th }} \mathrm{PD}-1^{+}$cells at baseline (placebo and vitamin $\mathrm{D}$ group, $N=20$ ). D. 25 -hydroxyvitamin $\mathrm{D}$ levels are associated with the percentage of $\mathrm{CD} 4^{+} \mathrm{CD} 25^{+ \text {+int }} \mathrm{PD}-1^{+}$at baseline (placebo and vitamin $\mathrm{D}$ group, $N=20$ ). 
TCR stimulation. Addition of $1.25(\mathrm{OH})_{2} \mathrm{D}$ reduced the PBMCs ability to up-regulate PD-L1 from 79\% (39 - 96\%) to $71 \%(50-94 \%)(p=0.008$ Figure $4 \mathrm{C})$. We examined if $1.25(\mathrm{OH})_{2} \mathrm{D}$ stimulation affected the $\mathrm{T}$ cell activation pattern in vitro. Addition of $1.25(\mathrm{OH})_{2} \mathrm{D}$ to TCRstimulated cells increased the T cells expression of CD69 from $55 \%(31-83 \%)$ to $80 \%(36-96 \%)(p<0.0001$, Figure 4D), and reduced their expressions of CD62L from $45 \%(26-81 \%)$ to $28 \%(16-54 \%)(\mathrm{p}=0.004$, Figure $4 \mathrm{E})$ and CD127 from $27 \%$ (13- 64\%) to $11 \%(10-25 \%)(p$ $=0.004$, Figure 4F). This, together indicates modulation towards a more activated $\mathrm{T}$ cell phenotype. However, in vitro $1.25(\mathrm{OH})_{2} \mathrm{D}$ stimulation resulted in a slightly reduced ability to up-regulate CD25 upon TCR activation from $86 \%(45-95 \%)$ to $81 \%(51-93 \%)(p=0.03$, Figure $4 \mathrm{G})$.

The PD-L2 expression was very low (below 1\% positive cells) and was unaffected by TCR and $1.25(\mathrm{OH})_{2} \mathrm{D}$ stimulation (data not shown). Supernatants from the cell culture (+/- antiCD3/CD28 and +/- 1.25(OH) 2 D) were examined for sPD-1 levels but these were unaffected by $1.25(\mathrm{OH})_{2} \mathrm{D}$ stimulation (data not shown).

\section{DISCUSSION}

PD-1 is a novel mediator of immune tolerance. The main finding in this study was an increased PD-1 up- regulation in $\mathrm{CD} 4{ }^{+} \mathrm{CD} 25^{\text {int }} \mathrm{T}$ cells from $\mathrm{CD}$ patients who received a daily supplement of vitamin $\mathrm{D}$, compared with CD patients treated with placebo for 26 weeks. Our data indicate that oral vitamin D modulates PD-1 signalling in $\mathrm{CD} 4{ }^{+} \mathrm{CD} 25^{+ \text {int }} \mathrm{T}$ cells from CD patients.

Vitamin D treatment increased the PD-1 expression in activated $\mathrm{CD} 4{ }^{+} \mathrm{CD} 25^{\text {int }} \mathrm{T}$ cells but not in the Tregenriched $\mathrm{CD} 4^{+} \mathrm{CD} 25^{\text {thi }}$ fraction. We have previously shown that vitamin $\mathrm{D}$ treatment did not induce $\mathrm{CD}^{+}{ }^{+} \mathrm{CD} 25^{+} \mathrm{FoxP}^{+} \mathrm{CD} 127^{-}$Treg in a similar patient cohort [28]. In healthy subjects, it has been demonstrated that vitamin D increases the amount of Tregs [29]. We did observe an association between 25-vitD levels and the amount of $\mathrm{CD} 4^{+} \mathrm{CD} 25^{\text {thigh }} \mathrm{PD}-1^{+} \mathrm{T}$ cells at baseline, but this association was not sustained by oral vitamin $\mathrm{D}$ or placebo treatment. The TCR-stimulation induced PD1-uregulation in $\mathrm{CD}^{+} \mathrm{T}$ cells was more pronounced in $\mathrm{CD}$ than in $\mathrm{HC}$, which is line with previous findings in patients with other chronic inflammatory diseases than CD [24, 30].

Upon TCR stimulation, oral vitamin D treatment to $\mathrm{CD}$ patients increased the up-regulation of PD-1 in $\mathrm{CD} 4{ }^{+} \mathrm{CD} 25^{\text {+int }} \mathrm{T}$ cells and inhibited the $\mathrm{T}$ cell activation pattern, indicated by a reduced CD69 up-regulation. This finding is in accordance with a study in healthy volunteers, where two months of high dose, daily vitamin D treatment also inhibited the $\mathrm{CD}^{+} \mathrm{T}$ cell's activation evaluated by

\section{$\mathrm{CD}^{+}$cells}

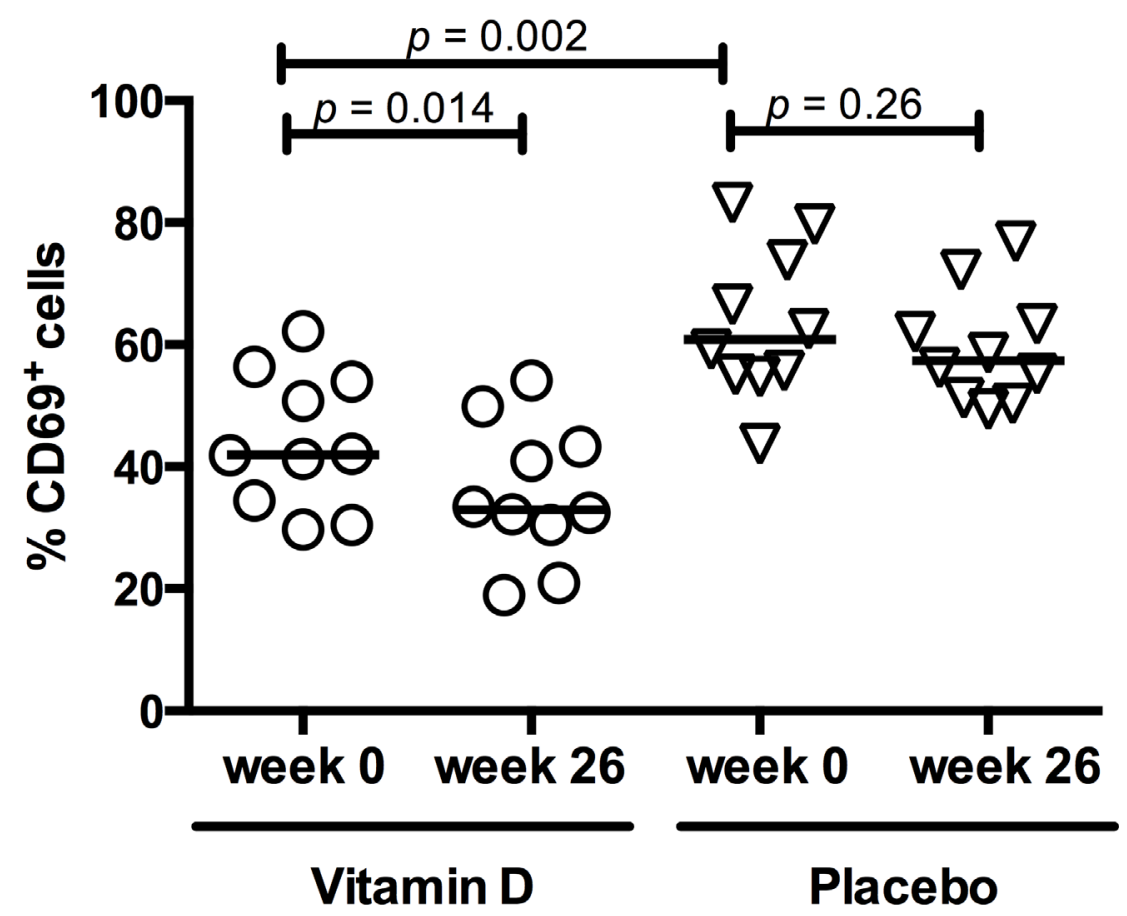

Figure 3: Vitamin D treatment reduced CD69 expression in active T cells. Circles represent vitamin D treated CD patients, triangles placebo treated CD patients and solid lines medians. 26 weeks of vitamin D treatment $(N=10)$ reduced the T cells' ability to upregulate CD69 upon TCR activation. This was not observed in the placebo group $(N=10)$. At baseline, CD69 expression was higher in the placebo group than the vitamin D group. 
A

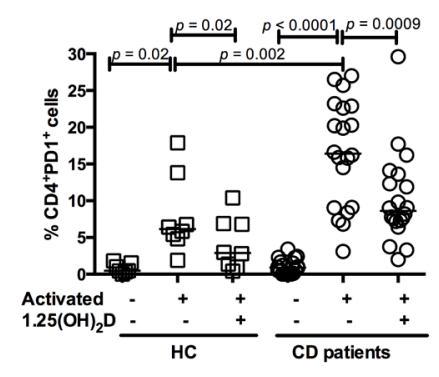

Baseline (CD; vitamin D + placebo group)

C

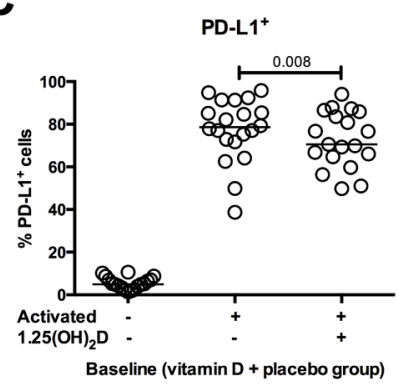

E
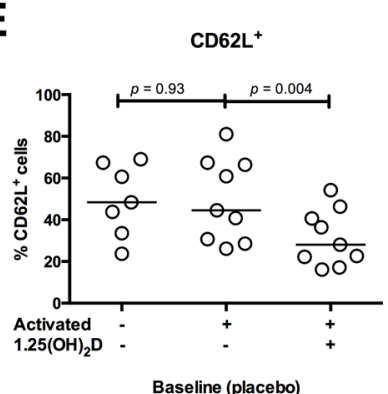

G

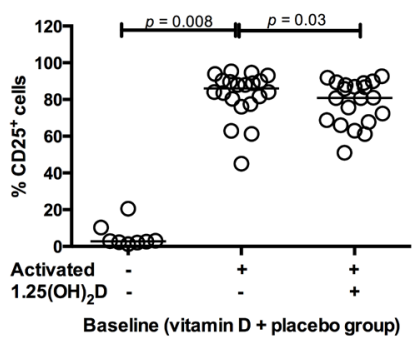

B $\quad$ CD8 $^{+}$PD-1 $1^{+}$

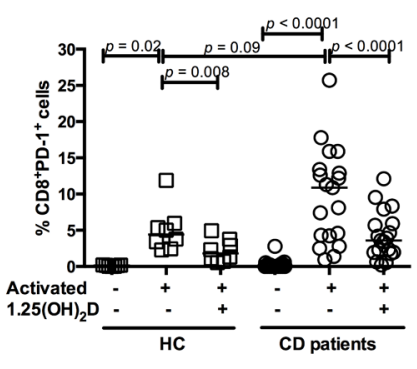

Baseline (CD; vitamin D + placebo group)

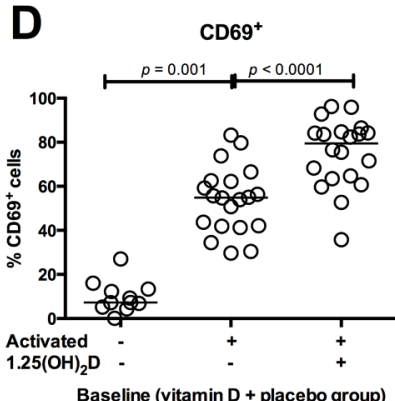

F $\quad \mathrm{CD}^{2} 7^{+}$

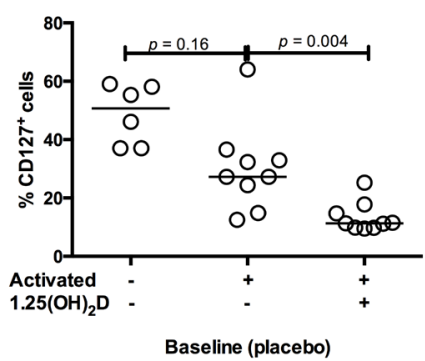

Figure 4: In vitro 1.25(OH)2D decreases PD-1 and activates T cells. The influence of in vitro $1.25(\mathrm{OH})_{2} \mathrm{D}$ stimulation on $\mathrm{T}$ cell activation markers and PD-1 from CD patients and HC. Solid lines represent median, squares represent HC and circles CD patients. All figures show baseline data why the CD vitamin D and placebo group are grouped together. A. In CD patients, TCR stimulation increased the PD-1 expression in $\mathrm{CD}^{+} \mathrm{T}$ cells more than in $\mathrm{HC}$. In vitro $1.25(\mathrm{OH})_{2} \mathrm{D}$ stimulation decreases the $\mathrm{CD} 4^{+} \mathrm{T}$ cells ability to express PD-1 in both $\mathrm{HC}(\mathrm{N}=8)$ and $\mathrm{CD}$ patients $(N=20)$. B. TCR stimulation increases PD-1 in CD8 ${ }^{+} \mathrm{T}$ cells similar in $\mathrm{HC}$ and $\mathrm{CD}$. In vitro $1.25(\mathrm{OH})_{2} \mathrm{D}$ stimulation decreases the $\mathrm{CD}^{+} \mathrm{T}$ cells' ability to express PD-1 in both $\mathrm{HC}(N=8)$ and $\mathrm{CD}$ patients $(N=20)$. C. TCR stimulation increases PD-L1 expression in PBMCs from CD patients, while addition of $1.25(\mathrm{OH})_{2} \mathrm{D}$ decreases the ability to express PD$\mathrm{L} 1(N=20)$. D. TCR stimulation increases the CD69 expression, which is further increased by in vitro $1.25(\mathrm{OH})_{2} \mathrm{D}$ stimulation in PBMCs $(N=20)$. E. CD62L expression was unaffected by TCR stimulation while $1.25(\mathrm{OH})_{2} \mathrm{D}$ stimulation decreases the ability to express $\mathrm{CD} 62 \mathrm{~L}$ in PBMCs from CD patients $(N=10)$. F. TCR stimulation did not affect the CD127 expression in PBMCs from CD patients but in vitro $1.25(\mathrm{OH})_{2} \mathrm{D}$ stimulation decreases the $\mathrm{CD} 127$ expression $(N=10)$. G. $\mathrm{CD} 25$ expression increases when PBMCs are stimulated with TCR. However, $1.25(\mathrm{OH})_{2}$ D stimulation decreased the $\mathrm{CD} 25$ expression $(N=20)$. Activated: stimulation with anti-CD3 and anti-CD28, vitamin D; $1.25(\mathrm{OH})_{2} \mathrm{D}$ stimulation, $\mathrm{HC}$; healthy controls, vitamin D CD; vitamin D treated Crohn's Disease patients, placebo CD; placebo treated Crohn's Disease patients, PD-1; programmed death 1. 
a decreased adenosintriphosphat (ATP) release [31]. Our results suggest that oral vitamin $\mathrm{D}$ treatment to $\mathrm{CD}$ patients may mediate reduced $\mathrm{T}$ cell activation by increasing the PD- 1 expression in $\mathrm{CD} 4{ }^{+} \mathrm{CD} 25^{+ \text {int }} \mathrm{T}$ cells.

We did not observe an association between the soluble PD-1 concentration and disease activity scores as observed in RA patients with active disease [19]. In the present study, all patients were in remission and were thus not comparable with the studied RA patients. The observed increased PD-1 expression in $\mathrm{CD} 4{ }^{+} \mathrm{CD} 25^{+ \text {int }} \mathrm{T}$ cells was not associated with an altered shedding of the PD-1 receptor. Our findings support data from the clinical study [6] where vitamin D inhibited inflammation and reduced the risk of relapse. We, and others have previously demonstrated an association between low 25-vitD levels and increased disease activity scores [32, 33] and faecal calprotectin levels [34]. These data support that vitamin D has immunoregulatory effects.

We also examined the effects of in vitro $1.25(\mathrm{OH})_{2} \mathrm{D}$ stimulation. Here, $1.25(\mathrm{OH})_{2} \mathrm{D}$ increased the activation of TCR-stimulated T cells, demonstrated by a decrease in CD127 and CD62L expressions and an increase in CD69 expression. Interestingly, PD-1 expression was strongly reduced by in vitro $1.25(\mathrm{OH})_{2} \mathrm{D}$ stimulation. This suggests that $\mathrm{T}$ cells respond differently to in vitro $1.25(\mathrm{OH})_{2} \mathrm{D}$ stimulation than to 26 week of in vivo vitamin $\mathrm{D}$ treatment. This may reflect that the in vitro conditions do not represent the in vivo setting. Alternatively, vitamin $\mathrm{D}$ could exert a dualistic regulation of $\mathrm{T}$ cells, initially activating the $\mathrm{T}$ cells and over time be switching to an inhibition of the $\mathrm{T}$ cell activation. This is not possible to decipher in the present study. Evidence to support the latter hypothesis remains ambiguous. Von Essen et al. showed that the phospholipase $\mathrm{C}$-dependent activation pathway of T cells depended on vitamin D activation [35]. Others have suggested that in vitro $1.25(\mathrm{OH})_{2} \mathrm{D}$ stimulation decreases $\mathrm{CD}^{+} \mathrm{CD} 25^{-} \mathrm{T}$ cells proliferation [30].

In the present study we used high CD25 expression to enrich for Tregs in our analysis. However, the discrimination of Tregs from activated $\mathrm{T}$ cells, solely by CD25 can be difficult [36, 37]. Just like other Treg markers such as $\mathrm{FoxP}^{+}$and $\mathrm{CD} 127^{-}, \mathrm{CD}^{+} \mathrm{CD} 25^{\text {thigh }}$ expression is not exclusive to Tregs, although the proportion of Tregs is considerably higher among the $\mathrm{CD} 4^{+} \mathrm{CD} 25^{\text {thi }}$ subset, than in the $\mathrm{CD} 4^{+} \mathrm{CD} 25^{\text {+int }}$ subset.

One important limitation in the present study is that our findings could be confounded by the increased use of azathioprine in the vitamin D treated group. In the original clinical trial, more patients received azathioprine in the vitamin D-treated group than in the placebo-treated group, but the difference was not statistically significant. Adjustment for use of azathioprine only changed the risk estimates slightly [6]. In the present study, we observed no associations between azathioprine use and cell surface markers, pointing to vitamin D treatment as the regulator of the expression of the investigated cell surface markers.
In conclusion, oral vitamin $\mathrm{D}$ treatment in $\mathrm{CD}$ patients increases the PD- 1 expression in $\mathrm{CD} 4^{+} \mathrm{CD} 25^{+ \text {int }} \mathrm{T}$ cells and decreases the CD69 expression. This may reflect that vitamin $\mathrm{D}$ influences immune tolerance through the PD-1 mediated modulation of T cell responses in Crohn's disease.

\section{MATERIALS AND METHODS}

\section{Participants}

A total of $108 \mathrm{CD}$ patients were included in a randomised placebo-controlled clinical trial [6]. Each patient was treated daily for one year with $30 \mu \mathrm{g}$ vitamin D3 and $1200 \mathrm{mg}$ calcium or placebo and calcium. In the present study, a subgroup was selected from the clinical trial. Twenty vitamin D3 treated patients were included, on the basis of a baseline 25-vitD serum level below $85 \mathrm{nmol} / 1$ combined with an increase in 25-vitD from baseline to week 26. Another 20 patients who had been randomised to placebo and who had baseline 25vitD levels below $85 \mathrm{nmol} / \mathrm{L}$ were included as a control group. Other patient characteristics were independent of the selection. Plasma samples from week 26 were available from all vitamin D-treated patients, but only from 11 of the placebo patients, due to drop-out $(N=3)$, exclusion because of relapse within 26 weeks $(N=4)$, and unavailable patient samples $(N=2)$. Plasma samples were isolated at week 0 and 26 and stored at $-140{ }^{\circ} \mathrm{C}$. Peripheral blood mononuclear cells (PBMC) were examined from 10 vitamin $\mathrm{D}$ and 10 placebo treated $\mathrm{CD}$ patients from the selected groups. PBMCs were isolated by density gradient separation (Ficoll-Paque, Amersham Biosciences, Uppsala, Sweden) at baseline and week 26, and stored at $-140^{\circ} \mathrm{C}$.

In both groups, the following inflammation markers and clinical scores were measured at weeks 0 and 26: faecal calprotectin, CRP, CDAI [38, 39] and HBI [40].

Eight $\mathrm{HC}$ were included for the examination of surface markers on PBMCs. PBMCs were isolated and stored as described above. An additional ten healthy volunteers were included in order to measure soluble PD-1 in plasma. All HC were treated with a high dose of vitamin D (bolus of $5 \mathrm{mg}$ vitamin D3 followed by $0.5 \mathrm{mg}$ vitamin D3 for 14 days). Plasma was isolated at day 0 and 15 and stored at $-140^{\circ} \mathrm{C}$.

\section{Culture of PBMCs}

PBMCs were thawed and diluted in RPMI 1640 and washed twice. Cells $\left(1 \times 10^{6} / \mathrm{ml}\right)$ were cultured in RPMI10 medium $\left(1 \times 10^{6}\right.$ cells/well)(RPMI 1640, penicillin and streptomycin, 10\% human heat-inactivated AB serum, and $1.5 \mathrm{ml} \mathrm{HEPES}$ ) and stimulated with or without $0.1 \mu \mathrm{g} / \mathrm{ml}$ 
immobilised anti-CD3 (Orthoclone OKT3; a kind gift from Cilag AG International, Schaffhausen, Switzerland) and with or without $10^{-8} \mathrm{M} 1.25$ dihydroxyvitamin $\mathrm{D}_{3}$ (SigmaAldrich, St Louis, MO, USA). One hour later $0.05 \mu \mathrm{g} / \mathrm{ml}$ soluble anti-CD28 (cat. no. 55BD Biosciences, San Diego, CA, USA) was added. PBMCs were cultured in 24-well plates (TPP, Trasadingen, Switzerland) for three days. Day three, the PBMCs were harvested, washed and suspended in PBS (5 x 106/ml). $100 \mu$ of the PBMC-suspension was stained with the surface markers: CD4 (cat. no. 555346, BD Pharmingen), CD8 (cat. no. 555369, BD Pharmingen), CD14 (cat. no. 345784, BD Bioscience), CD19 (cat. no. 557791, BD Pharmingen), CD25 (cat. no. 557741, BD Pharmingen), CD69 (cat. no. 310910, BioLegend), PD-1 (cat. no. 557946, BD Pharmingen), PD-L1 (cat. no. 329718, BioLegend), PD-L2 (cat. no. 557926, BD Pharmingen), CD62L(cat. no. 304816, BD Pharmingen), CD127(cat. no. 557938, BD Pharmingen) and Via Probe (cat. no. 555815, BD Bioscience), and incubated 30 minutes in the dark at $4^{\circ} \mathrm{C}$. The cells were subsequently washed and resuspended in $250 \mu \mathrm{l}$ fixating buffer (PBS, $1 \%$ formaldehyde). Cells were analysed by flow cytometry within 24 hours. The $\mathrm{CD} 4{ }^{+} \mathrm{CD} 25^{+}$population was divided into $\mathrm{CD} 4^{+} \mathrm{CD} 25^{+ \text {high }}\left(\mathrm{CD} 4^{+} \mathrm{CD} 25^{\text {thi }}\right.$, the $5 \%$ of cells with the highest $\mathrm{CD} 25$ expression) and $\mathrm{CD} 4{ }^{+} \mathrm{CD} 25^{+}$intermediate $\left(\mathrm{CD} 4{ }^{+} \mathrm{CD} 25^{+ \text {int }}\right.$, the remaining $95 \%$ of $\mathrm{CD} 4{ }^{+} \mathrm{CD} 25^{+} \mathrm{T}$ cells). Then PD-1 expression was analysed in each cell subset (Figure S1). Only live, single cells were included and gates were based on isotype or FMO controls.

\section{Enzyme-linked immunosorbent assay (ELISA)}

A sandwich ELISA was used to quantify plasma and supernatant levels of sPD-1. sPD-1 levels were analysed according to the manufacturer's instructions using DuoSet Human PD-1 (R\&D systems, Minneapolis, MN). Plasma samples were diluted 1:2 in Reagent dilution (phosphatebuffered saline (PBS), $40 \mu \mathrm{g} / \mathrm{ml}$ bovine antigen (Jackson Immunoresearch, Suffolk, UK) and $20 \mu \mathrm{g} / \mathrm{ml}$ goat antigen (Jackson) to ensure pre-aggregation of heterophilic antibodies in the samples. Supernatant samples were not diluted. The minimum detection limit was $0.05 \mathrm{ng} / \mathrm{ml}$, and values below the detection limit were assigned the value of the detection limit. Samples were analysed in duplicate and the average optical density (OD) values were used to determine the concentrations. The sPD-1 ELISA has previously been validated [19].

\section{Faecal calprotectin}

Calprotectin levels $(\mathrm{mg} / \mathrm{kg})$ were quantified in stool samples with the ELISA kit Phical Test/Calprotectin (NovaTec Immundiagnostica $\mathrm{GmbH}$, Dietzenbach, Germany). The range was from 20 to $1250 \mathrm{mg} / \mathrm{kg}$. The levels 20 represented levels $\leq 20 \mathrm{mg} / \mathrm{kg}$ and the given levels at 1250 represented levels $\geq 1250 \mathrm{mg} / \mathrm{kg}$ (outliers were truncated).

\section{Statistics}

Comparison of baseline characteristics between the vitamin D and placebo treated group were analysed with Chi square test or Wilcoxon rank sum test. We used nonparametric Wilcoxon rank sum test to compare unpaired data and Wilcoxon signed rank test with paired data. Results are presented as median with range. An association between two variables was estimated using Spearman's rank correlation coefficient (Spearman's rho). A p-value below 0.05 was considered statistically significant. All the statistical analyses and graphs were completed using GraphPad Prism version 6 (GraphPad Software Inc., La Jolla, CA, USA).

\section{Ethics}

The clinical study (which provided patient samples to the present study) and additional studies based on the collected patient samples were approved by the National Committee on Health Research Ethics (j. no. 2004/0149) and the Danish Medicines Agency (EudraCT no. 2005/001216/50) and was registered at ClinicalTrial. gov (NCT 0013 2184). In the randomized clinical trial, the patients signed written informed consent and approved that blood samples were stored for further studies on the effects of vitamin D in CD. The clinical trial conformed to the Helsinki Declaration and to Danish legislation. Patients gave informed consent to participate in the study [6]. The 10 vitamin D-treated healthy controls are controls in an on-going clinical study, which has been approved by the regional Committee of Ethics (j.no. 51462) and the Danish Medicines Agency (EudraCT no. 2013-00097134). Healthy controls gave informed consent to participate in the study and signed and approved that blood samples were stored for further studies on the effects of vitamin D in healthy controls.

\section{Abbreviations}

CD, Crohn's Disease; HC, healthy controls; 1.25(OH)2D, 1.25-dihydroxyvitamin D3; 25-vitD, 25-hydroxyvitamin D; PD-1, programmed death 1; PD-L1, programmed death ligand 1; PD-L2, programmed death ligand 2; PBMCs, peripheral blood mononuclear cells; IL, interleukin; TNF $\gamma$, tumour necrosis factor alpha; IFN- $\gamma$, interferon gamma; CDAI, Crohn's disease activity index; HBI, Harvey-Bradshaw index; CRP, C-reactive protein; TCR, T cell receptor; CD4+CD25+hi, CD4+CD25+high; CD4+CD25+int, CD4+CD25+intermediate; ATP, adenosintriphosphat; LPS, lipopolysaccharides; Treg, regulatory T cells; Th17 cells, T helper 17 cells. 


\section{Author contributions}

M. Bendix performed the research, analysed the data, designed the research study and wrote the paper. SR Greisen contributed to design, the research and the writing of the paper. A Dige contributed to data analysis and writing of the paper. CL Hvas contributed to the data collection and writing of the paper. NF Bak and SP Jørgensen collected data and contributed to the data analysis. JF Dahlerup contributed to the study design. B Deleuran contributed to study design, data analysis and writing of the paper. J Agnholt contributed to data analysis and writing of the paper. All authors have approved the final version of the article including the authorship list.

\section{ACKNOWLEDGMENTS}

We thank laboratory technician Karin Skovgaard Sørensen for expert laboratory technical support.

\section{CONFLICTS OF INTEREST}

Jørgen Agnholt has served as a speaker for Janssen Cilag and BMS and an advisory board member for Abbvie, MSD, Takeda, Pfizer and Ferring Pharmaceuticals. The remaining authors declare no conflicts of interest.

\section{FUNDING}

This study was funded in part by the Beckett Foundation and in part by the Danish Colitis Crohn foundation.

\section{Editorial note}

This paper has been accepted based in part on peerreview conducted by another journal and the authors' response and revisions as well as expedited peer-review in Oncotarget.

\section{REFERENCES}

1. de Bruyn JR, van Heeckeren R, Ponsioen CY, van den Brink GR, Lowenberg M, Bredenoord AJ, Frijstein G, D'Haens GR. Vitamin D deficiency in Crohn's disease and healthy controls: A prospective case-control study in the Netherlands. J Crohns Colitis. 2014; 8:1267-1273.

2. Bours PH, Wielders JP, Vermeijden JR, van de Wiel A. Seasonal variation of serum 25-hydroxyvitamin D levels in adult patients with inflammatory bowel disease. Osteoporos Int. 2011; 22:2857-2867.

3. Ulitsky A, Ananthakrishnan AN, Naik A, Skaros S, Zadvornova Y, Binion DG, Issa M. Vitamin D deficiency in patients with inflammatory bowel disease: association with disease activity and quality of life. JPEN J Parenter Enteral Nutr. 2011; 35:308-316.

4. Torki M, Gholamrezaei A, Mirbagher L, Danesh M, Kheiri S, Emami MH. Vitamin D Deficiency Associated with Disease Activity in Patients with Inflammatory Bowel Diseases. Dig Dis Sci. 2015; 60:3085-3091.

5. Ham M, Longhi MS, Lahiff C, Cheifetz A, Robson S, Moss AC. Vitamin D levels in adults with Crohn's disease are responsive to disease activity and treatment. Inflamm Bowel Dis. 2014; 20:856-860.

6. Jorgensen SP, Agnholt J, Glerup H, Lyhne S, Villadsen GE, Hvas CL, Bartels LE, Kelsen J, Christensen LA, Dahlerup JF. Clinical trial: vitamin D3 treatment in Crohn's disease - a randomised double-blind placebo-controlled study. Aliment Pharmacol Ther. 2010; 32:377-383.

7. Bendix M, Dige A, Deleuran B, Dahlerup JF, Peter Jorgensen S, Bartels LE, Husted LB, Harslof T, Langdahl B, Agnholt J. Flow cytometry detection of vitamin D receptor changes during vitamin D treatment in Crohn's disease. Clin Exp Immunol. 2015; 181:19-28.

8. Fawaz L, Mrad MF, Kazan JM, Sayegh S, Akika R, Khoury SJ. Comparative effect of 25(OH)D3 and 1,25(OH)2D3 on Th17 cell differentiation. Clin Immunol. 2016; 166-167:5971.

9. Urry Z, Chambers ES, Xystrakis E, Dimeloe S, Richards DF, Gabrysova L, Christensen J, Gupta A, Saglani S, Bush A, O'Garra A, Brown Z, Hawrylowicz CM. The role of 1alpha,25-dihydroxyvitamin D3 and cytokines in the promotion of distinct Foxp3+ and IL-10+CD4+ T cells. Eur J Immunol. 2012; 42:2697-2708.

10. Baumgart DC, Sandborn WJ. Crohn's disease. Lancet. 2012; 380:1590-1605.

11. Spalinger MR, Rogler G, Scharl M. Crohn's disease: loss of tolerance or a disorder of autophagy? Dig Dis. 2014; 32:370-377.

12. Keir ME, Butte MJ, Freeman GJ, Sharpe AH. PD-1 and its ligands in tolerance and immunity. Annu Rev Immunol. 2008; 26:677-704.

13. Sharpe AH, Wherry EJ, Ahmed R, Freeman GJ. The function of programmed cell death 1 and its ligands in regulating autoimmunity and infection. Nat Immunol. 2007; 8:239-245.

14. Yang W, Chen PW, Li H, Alizadeh H, Niederkorn JY. PD-L1: PD-1 interaction contributes to the functional suppression of T-cell responses to human uveal melanoma cells in vitro. Invest Ophthalmol Vis Sci. 2008; 49:25182525 .

15. Okazaki T, Honjo T. PD-1 and PD-1 ligands: from discovery to clinical application. Int Immunol. 2007; 19:813-824.

16. Shi B, Du X, Wang Q, Chen Y, Zhang X. Increased PD-1 on CD4(+)CD28(-) T cell and soluble PD-1 ligand-1 in patients with T2DM: association with atherosclerotic 
macrovascular diseases. Metabolism. 2013; 62:778-785.

17. Pedoeem A, Azoulay-Alfaguter I, Strazza M, Silverman GJ, Mor A. Programmed death-1 pathway in cancer and autoimmunity. Clin Immunol. 2014; 153:145-152.

18. Dai S, Jia R, Zhang X, Fang Q, Huang L. The PD-1/PD-Ls pathway and autoimmune diseases. Cell Immunol. 2014; 290:72-79.

19. Greisen SR, Rasmussen TK, Stengaard-Pedersen K, Hetland ML, Horslev-Petersen K, Hvid M, Deleuran B. Increased soluble programmed death-1 (sPD-1) is associated with disease activity and radiographic progression in early rheumatoid arthritis. Scand J Rheumatol. 2014; 43:101-108.

20. Lee JC, Lyons PA, McKinney EF, Sowerby JM, Carr EJ, Bredin F, Rickman HM, Ratlamwala H, Hatton A, Rayner TF, Parkes M, Smith KG. Gene expression profiling of CD8 $+\mathrm{T}$ cells predicts prognosis in patients with Crohn disease and ulcerative colitis. J Clin Invest. 2011; 121:41704179.

21. McKinney EF, Lee JC, Jayne DR, Lyons PA, Smith KG. T-cell exhaustion, co-stimulation and clinical outcome in autoimmunity and infection. Nature. 2015; 523:612-616.

22. Yi JS, Cox MA, Zajac AJ. T-cell exhaustion: characteristics, causes and conversion. Immunology. 2010; 129:474-481.

23. Frebel H, Nindl V, Schuepbach RA, Braunschweiler T, Richter K, Vogel J, Wagner CA, Loffing-Cueni D, Kurrer M, Ludewig B, Oxenius A. Programmed death 1 protects from fatal circulatory failure during systemic virus infection of mice. J Exp Med. 2012; 209:2485-2499.

24. Kanai T, Totsuka T, Uraushihara K, Makita S, Nakamura T, Koganei K, Fukushima T, Akiba H, Yagita H, Okumura $\mathrm{K}$, Machida U, Iwai H, Azuma M, et al. Blockade of B7-H1 suppresses the development of chronic intestinal inflammation. J Immunol. 2003; 171:4156-4163.

25. Song MY, Hong CP, Park SJ, Kim JH, Yang BG, Park Y, Kim SW, Kim KS, Lee JY, Lee SW, Jang MH, Sung YC. Protective effects of Fc-fused PD-L1 on two different animal models of colitis. Gut. 2015; 64:260-271.

26. Unger WW, Laban S, Kleijwegt FS, van der Slik AR, Roep BO. Induction of Treg by monocyte-derived DC modulated by vitamin D3 or dexamethasone: differential role for PDL1. Eur J Immunol. 2009; 39:3147-3159.

27. Huang Y, Zhao Y, Ran X, Wang C. Increased expression of herpesvirus entry mediator in 1,25-dihydroxyvitamin D3-treated mouse bone marrow-derived dendritic cells promotes the generation of CD4(+)CD25(+)Foxp3(+) regulatory T cells. Mol Med Rep. 2014; 9:813-818.

28. Bendix-Struve M, Bartels LE, Agnholt J, Dige A, Jorgensen SP, Dahlerup JF. Vitamin D3 treatment of Crohn's disease patients increases stimulated T cell IL-6 production and proliferation. Aliment Pharmacol Ther. 2010; 32:13641372.

29. Bock G, Prietl B, Mader JK, Höller E, Wolf M, Pilz S, Graninger WB, Obermayer-Pietsch BM, Pieber TR. The effect of vitamin $\mathrm{D}$ supplementation on peripheral regulatory T cells and $\beta$ cell function in healthy humans: a randomized controlled trial. Diabetes Metab Res Rev. 2011; 27:942-945.

30. Alahgholi-Hajibehzad M, Oflazer P, Aysal F, Durmus H, Gulsen-Parman Y, Marx A, Deymeer F, SaruhanDireskeneli G. Regulatory function of CD4+CD25++ $\mathrm{T}$ cells in patients with myasthenia gravis is associated with phenotypic changes and STAT5 signaling: 1,25-Dihydroxyvitamin D3 modulates the suppressor activity. J Neuroimmunol. 2015; 281:51-60.

31. Konijeti GG, Arora P, Boylan MR, Song Y, Huang S, Harrell F, Newton-Cheh C, O’Neill D, Korzenik J, Wang TJ, Chan AT. Vitamin D Supplementation Modulates $\mathrm{T}$ Cell-Mediated Immunity in Humans: Results from a Randomized Control Trial. J Clin Endocrinol Metab. 2016; 101:533-538.

32. Jorgensen SP, Hvas CL, Agnholt J, Christensen LA, Heickendorff L, Dahlerup JF. Active Crohn's disease is associated with low vitamin D levels. J Crohns Colitis. 2013; 7:e407-413.

33. Raffner Basson A, Swart R, Jordaan E, Mazinu M, Watermeyer G. Vitamin D Deficiency Increases the Risk for Moderate to Severe Disease Activity in Crohn's Disease Patients in South Africa, Measured by the Harvey Bradshaw Index. J Am Coll Nutr. 2016; 35:163-174.

34. Raftery T, Martineau AR, Greiller CL, Ghosh S, McNamara D, Bennett K, Meddings J, O’Sullivan M. Effects of vitamin D supplementation on intestinal permeability, cathelicidin and disease markers in Crohn's disease: Results from a randomised double-blind placebo-controlled study. United European Gastroenterol J. 2015; 3:294-302.

35. von Essen MR, Kongsbak M, Schjerling P, Olgaard K, Odum N, Geisler C. Vitamin D controls T cell antigen receptor signaling and activation of human $\mathrm{T}$ cells. Nat Immunol. 2010; 11:344-349.

36. Aerts NE, Dombrecht EJ, Ebo DG, Bridts CH, Stevens WJ, De Clerck LS. Activated T cells complicate the identification of regulatory $\mathrm{T}$ cells in rheumatoid arthritis. Cell Immunol. 2008; 251:109-115.

37. Roncarolo MG, Gregori S. Is FOXP3 a bona fide marker for human regulatory T cells? Eur J Immunol. 2008; 38:925927.

38. Best WR, Becktel JM, Singleton JW, Kern F Jr. Development of a Crohn's disease activity index. National Cooperative Crohn's Disease Study. Gastroenterology. 1976; 70:439-444.

39. Best WR, Becktel JM, Singleton JW. Rederived values of the eight coefficients of the Crohn's Disease Activity Index (CDAI). Gastroenterology. 1979; 77:843-846.

40. Harvey RF, Bradshaw JM. A simple index of Crohn'sdisease activity. Lancet. 1980; 1:514. 